\title{
INTERNET

\section{A Netnographic Study on Virtual Community of Patients with Spinal Cord Injury (SCI) in Turkey *}

\section{Türkiye'de omurilik yaralanmalı hastaların oluşturduğu sanal topluluklar üzerinde netnografik bir araştırma}

\author{
Mehpare TOKAY ARGAN 1, mehpare.argan@bilecik.edu.tr \\ Metin ARGAN ${ }^{2}$, margan@anadolu.edu.tr \\ Alper ÖZER 3, ozer@politics.ankara.edu.tr
}

Internet has been reported as one of the most important place that patients with SCI share their experiences. The literature suggests that patients having SCI have some online experiences on web as helpful during their remaining lives. However, there are only a few studies about the communication of Turkish patients of spinal cord injury (SCI). This exploratory, qualitative netnographic study was aimed to reveal the experiences of a virtual community comprised patients with SCI. While netnographic analysis offers a potentially suitable approach for various virtual communities, this study applied a netnography approach and was based on data from a SCI community. The results of this study indicated that six main forums that the patients can mainly involve in the forums and suggested the need for changes of virtual community perception and group interaction experiences. It is also found that interest in the medical news relating to the hope of recovery was the most important factor.

Keywords: Netnographic study, Online communities, Spinal cord injuries

Jel Codes: M31, I11, I18.
Internet, omurilik hastalarının deneyimlerini paylaştıkları önemli bir ortam olarak öne çımaktadır. Literatür, omurilik rahatsızlı̆̆ına sahip olan hastalarm web üzerinden deneyimlerini paylaşmalarının oldukça yardımoı bir araç olduğunu göstermektedir. Bununla birlikte, Türkiye'de omurilik rahatsızlı̆̆ına sahip olanların iletişimine ilişkin olarak az sayıda çalışma bulunmaktadır. Keşifsel, nitel araştırmanın yapıldığı bu çalışmada nitel araștırma yöntemlerinden netnografik araştırma yöntemi kullanılarak, omurilik hastalarının oluşturduğu sanal topluluklardaki deneyimler ortaya çıkarlmaya çalışılmıştır. Araştırma, omurilik hastalarının üye olduğu sanal topluluklardan elde edilen veriler kullanılmıştır. Çalışma sonuçları, hastaların genel olarak altı farklı forumda deneyimlerini paylaştıkların, sanal topluluklardaki algıda ve grup etkileşiminde farklılıkların söz konusu olduğunu ortaya koymaktadır. Araştırma ayrica, iyileşme umuduna ilişkin haberlere yönelik ilginin en önemli etken faktör olarak ortaya çıtı̆̆ııı göstermektedir.

Anahtar Kelimeler: Netnografik araştırma, Sanal topluluklar, Omurilik yaralanmaları

Jel Kodlari: M31, I11, I18.

\footnotetext{
* This study was submitted as a poster presentation at 21st Qualitative Health Research Conference, October 19-21, 2015, Toronto, Ontario, Canada.

${ }^{1}$ Assoc. Prof. Dr., Bilecik Şeyh Edebali University, School Of Applied Sciences (Corresponding author)

2 Prof. Dr., Anadolu University, Faculty of Sport Sciences

${ }^{3}$ Assoc. Prof. Dr., Ankara University, Faculty of Political Science
} 


\section{INTRODUCTION}

The spinal cord injury (SCI) incidence varies between 15 and 40 per million (Sayılır, Ersöz \& Yalçın, 2013). It has been reported 12000 new cases per year in United States (Y1lmaz, Turan \& Keleş, 2014). Considering Turkey's population is approximately 78 million by 2015, it is possible to say that there are between 1170 and 3120 incidences per year in Turkey. There are several reasons for SCI, such as motor vehicle accidents, sports and leisure injures, workrelated accidents, beaten injures, and falls at home (Y1lmaz, Turan \& Keleş, 2014). Spinal cord injury (SCI) is a serious and chronic health problem that leads to social (Kurtaran et al., 2009) and psychological consequences both in the life of an individual and on his/her family. General population of the SCI accidents are health young adults who are between the ages of 15-25. These young patients have serious social (Yılmaz, Turan \& Keleş, 2014) and psychological problems. One of the most important environment or platform that contributes to socialization, psychological therapy, of SCI patients is participation in a virtual community.

Virtual communities continue to grow in number since the emergence of the Internet (Camerini, Diviani \& Tardini, 2010). In recent years, virtual communities have served as a meeting point for interaction platform of many patients with specific or serious disease. Empirical studies on the support groups by interact with other people with similar problems by patients in Turkey are typically widespread among people with a serious illness and have become a necessity for the level of health-related information sharing. A virtual community enable access for engaging in common activities, sharing feelings, or discussing ideas with feelings (Lee, Vogel \& Limayem, 2003). Chen, Chang \& Liu (2012) state that "virtual communities typically emerge as a results of participants coming together on the Internet for discussing on topics that may include a common hobby, a medical affliction, a personal feeling or experience, or even the development of new relationships (p.640). Virtual community facilitates interaction and communication among its members. Virtual communities have functions in many ways, such as information source, social interaction, share experiences, share concerns, and psychological supports (Annett-Hitchcock \& Xu, 2015).

The use of the social media and virtual groups on internet can develop the relationships among patients with chronic disease. Little research to date has explored virtual group experiences of patients with SCI and the impact on socializations in Turkey. Understanding patients having serious or special diseases have always been the main aim in health care marketing. In millennium, gaining new data and experiences from patients' online activities is one of the basic methods for a better understanding of them. Experience is considered essential for life survival and perseverance among people having serious health problems or disease. The virtual communities regarding specific diseases have become more common and more important in some areas in recent decades as social media platforms opened up possibilities for patients to educate and support themselves. As pointed out by the authors, virtual communities or social media forums create a possibility for people to become more experienced and more connected life. As a consequence, the interest in patients' experience has increased at a phenomenal rate. 
Several disease-specific online groups now exist on internet and social media, such as Facebook and other online social media sites. These virtual or inline groups have become significant sources in terms of sharing, socializing, searching, interacting for people with chronic disease.

Greene et al. (2011) states that patients search on internet more frequently than they communicate with their doctors about health problems. Moreover, patients also seek to meet and interact with a community of patients with similar problems (Greene et al., 2011). With this aspect, virtual communities on internet act as a socializing medium.

Based on these literature approaches on virtual communities, the current study seeks to answer the question of what constitutes experiences of patients with serious health disease. In order to better understand the patients' experience in the current study, it is important to underline internet experiences of patients as virtual communities. Therefore, the purpose of this netnographic study is to investigate the use of virtual community for patients with SCI problems and to explore the role that this health-related community plays in their life experiences.

\section{VIRTUAL HEALTH COMMUNITIES}

Recently, one of the most significant development in the health field has been the internet. Internet medium has led to groundbreaking developments in health-related perspectives from different approaches. Additionally, virtual health communities have attracted many scholars from different academic areas, such as marketing, economics, communication, and sociology (Loane \& D'Alessandro, 2013). Virtual community in health, reflected by interactive communication, is central to gain specific disease-related information and to share experiences among patients. Patient-centered information and experience sharing become one of the dominant features of today's online era. Especially with the increasing number blogs and community support communities and social media, patient-oriented virtual communities has increased. Therefore, one platform of support for patients experiencing socialization and exchange of information is online support groups or virtual communities. Patients with common interests or disease gather virtually to share their health experience, ask questions, or provide emotional benefits and self-support (Eysenbach et al., 2004). A typical virtual community in health include a group of people (patients, doctors, professionals, members of general public) who have come together to share health information and personal experiences (Demiris, 2006). According to Eysenbach et al. (2004), virtual communities can be seen mental health and social support mediums.

Virtual health communities represent a vulnerable population who need to connect via online social support groups (Davis \& Calitz, 2014). According to Symister and Friend (2003), lack of belongingness may result in feelings of social isolation, loneliness, negative mood and hopelessness. Health-related virtual communities provide significant benefits to members, including cope with depression, decrease stress, share opinion and experiences (Loane \& D'Alessandro, 2013). For this reason, virtual communities help chronically ill patients who want to maintain a positive mood and optimism (Davis \& Calitz, 2014).

Typical examples of application in virtual health community are bulletin boards and forums (Camerini, Diviani \& Tardini, 2010). Individuals with same health problems ascertain to 
come together and to communicate with an online group of patients, both to share information obtained relating to health and to establish social relations among patients (Greene et al., 2011). Many patients with a serious disease already want to share narratives of their illness on personal web pages and virtual patient communities such as Turkey spinal cord paralyzed platform (http://www.omurilikfelclileri.com). Serious diseases with the potential to isolate individuals from the community is one of the most important problems both socially and psychologically.

Many health related virtual communities open to the general public and host to many forums. Members of these communities express themselves through these forums. In most cases, forums of virtual communities are categorized according to subject areas. According to the forum categorization, the members of the virtual community share their thoughts and experiences, and other members read, respond or like these shares. So, interaction occurs between members of health related virtual community.

Many studies are treated with therapeutic aspects of virtual health communities (Camerini, Diviani \& Tardini, 2010). The most important purpose in chronic health communities is to distance patients from loneliness, to develop relationships with new people, to continue the socialization process that eliminates the disease, to escape from the illness worldwide. So, therapy becomes important when the issues considered in the context of e-leisure. In today, online and mobile world can be considered the most important socializing agent. Therefore, investigation of therapy perspective of virtual health community will draw a useful framework. Virtual health communities provide alternative approaches to illness, social and psychological support and counseling from members with same disease (Bratucu et al., 2014). Thus, virtual communities created by members with same health problems offers services in this sense.

Concerning the motivation in participation to a virtual community, a potential benefit relates to interact and share experience among patients with the same health conditions. This is because a social networking and obtaining information about the disease may increase the willingness to live among patients with chronic health problems, despite all the difficult conditions. Thus, Welbourne, Blanchard and Wadsworth (2013) investigates motivates to participate in virtual communities and indicates two main motivations that have been identified in the virtual health communities literature are desire for informational support and socio-emotional support. Furthermore, while the experiences sharing helps other patients to cope with chronic illness and provides support and interactions (Winkelman \& Choo, 2012), many of patients' relatives are comfortable with this kind of virtual health community.

From the perspective of members, virtual communities have following features: belonging to community, social bonding, shared interests among other peers (Bratucu et al., 2014), and sharing or gaining health information. Eventually, virtual communities related with chronic disease can be expressed as a facilitator to share information and experience among patients. Klemm et al. (1999) identified different types of information-sharing about the content of a forum on cancer, including disease information research, information providing, the sharing of experience and personal opinion (Camerini, Diviani \& Tardini, 2010). Moreover, Hoybye et al. (2005) applied an ethnographic case study to explore Scandinavian breast cancer group 
on the Internet can break the social isolation. The finding of this study shows that the patients were empowered by the exchange of knowledge and sharing their experiences (Demiris, 2006; Hoybye et al., 2005). Huang, Chengalur-Smith and Ran (2014) carried out a research on virtual communities of breast cancer and prostate cancer's patients and concluded that individual participate virtual communities not just to exchange social support, but also for a sense of belonging and to engage in companionship activities.

\section{METHOD}

In this study, sharing interactions, experiences and health information among patients with SCI were analyzed using netnography method in order to understand their perceptions, attitudes, and feelings on an online platform. Netnography was first defined by Kozinets (1997). Kozinets used netnography in 1997 in a study about fans of The X Files (O'Reilly et al., 2012), defined it as "a written account of online cyber-culture, informed by the methods of cultural anthropology" (Kozinets, 1997, p.472). Netnography is a contemporary qualitative research methodology (Kozinets, 1997, 1998, 1999, 2002; O'Reilly et al., 2007) that has been applied in the many field as an appropriate method to assess and understand online persons. Netnography emerged as the application of ethnography for observing and studying cultures and communities formed through online communications (La Rocca, Mandelli \& Snehota, 2014, p. 691). Pettigrew et al. (2013) underlines that netnography as a form of online data collection comprises a blend of ethnography, content analysis, and discourse analysis. The salient features of the netnography are realistic, unsolicited, unobtrusive, less intrusive, less time consuming inexpensive than ethnography (Kozinets, 2002; Kozinets, 2006; O'Reilly et al., 2012).

The purpose of ethnography is to observe and describe behaviors, meanings and languages, interpreting and extracting patterns and codes of conduct, that is, unwritten rules and frames of reference, indicating shared and therefore cultural meanings. Netnography as a research approach is linked to the nature and development of social media (La Rocca, Mandelli \& Snehota, 2014, p. 691). According to Rageh, Melewar \& Woodside (2013) "experience is something singular that happens to an individual and which researchers cannot directly access" (p. 131). Therefore, researchers only interpret what their subjects have expressed orally, in writing or through their behavior. It is argued that netnography is the best method to examine experience because individuals usually write their reviews after their stay ends, so their experience is not affected by observation (Kozinets, 2002; Rageh, Melewar \& Woodside, 2013, p.131).

Kozinets (2002,) proposes the following steps with regard to the implementation of nethnography procedures. Entree: the identification the research questions and specific virtual community, especially through search engines. Data collection and analysis: Copying of data on virtual communities and examining in depth regarding observations, interactions, and meanings about virtual community members. Trustworthy interpretation: to focus on "trustworthiness" rather than "validity," and focus on procedures of classification, coding, reporting and triangulation. Research ethics: (1) Researchers should explain the presence to online community members during any research; (2) the researchers should ensure confidentiality and anonymity to informants; and (3) the researcher should seek and incorporate feedback from members of the online community being researched. (4) The 
researcher should take a cautious position on the private-versus-public medium issue. Member checks: presenting some or all of a final research report's findings to the members who have been studied in order to solicit their comments (p.63-66). This research is based on the execution of these steps netnography method.

In order to have in-depth knowledge about patients' experiences in a virtual community concerning with specific health problem, netnography was used for data analysis and interpretation. In this vein, this study adopts a netnography study approach for investigating and analyzing how patients with SCI express their feelings on experiences on www.omurilikfelclileri.com. According to Hartley (2004) a single case study is suited to research that "explores new and emerging process of behavior" and allows researchers greater opportunity to explore a subject in more depth (Keeling, Khan \& Newholm, 2013). Spinal cord paralysis platform in Turkey investigated for this netnography study was selected based on several criteria of having public online community and having open membership system. The individuals who have an interest in spinal cord paralysis access the related web site to see pasts made by peers or others. This web site is a virtual community developed by people with similar health problems or disease. The members on this community discuss various issues and disease-oriented ideas, share their experiences and make social interaction. The period of the study was from the end of February 2015 to mid of May 2015. Due to the large information amount of forums in the website, only the most widely read forums and have the most issues in these forums were analyzed. Therefore, the final sample contained six main forums, a total of 5864 issues and 9916 responses.

\section{RESULTS}

\section{Forums}

In the scope of this netrografhic study, the forums under the Platform of Spinal Cord Injuries, the forums where injured people receive and share news and support eachother, were studied. After analyzing this online community, in six different forums, the most read and replied forums were considered. Details are given below.

\section{Current issues}

In this title of the forum, questions and information related to spinal cord injuries. We can evaluate the information and the level of attention to this forum with the amount of the replies and how many times participants read. The title of the most read section in this forum is "I am having a Stem Cell Surgery". Participants read 21.867 times and responded 125 times. Another forum is titled as "The pen of Veysel Çelebi" that respondents read 10690 times and responded 88 times and the forum titled "Is there anyone using needle for tendon development?" was read 8349 times and received 21 responses. Subtopics of this forum mainly contain the subjects related to health. The people who follow this virtual community mainly seek information about their diseases. Some people seldomly use this virtual community to share different than health such as real life experiences or poems. Experiences and of participants' emotional intensity seem to be the reason for the high number of responses. 


\section{Spinal Cord Injury General}

There are seven sub forums in this section and each subforum includes the subjects in different levels. Stem Cell forum has 253 subjects and 1051 sub-subjects. Another subforum is titled as "Our Experiences" which has 121 subjects and 862 responses. The forum titled as "I am having a Stem Cell Surgery" received the highest number responses as participants most read and categorized as an active forum. One of the participants expressed the feelings as below:

"This subject is really important for me and everyone who is paralyzed, even for partially paralyzed ones. I will share all my experiences about surgery and situation after the surgery with all the members and the visitors of the forum. I ask all the prayers. I hope there will be positive results from these efforts and paralyzed people will benefit."

Most of the answers given to participant's stem cell surgery are related to pray and wishes supported with religious issues. We observed that responses include expectation and hope before the surgery, hope after the surgery, and sadness while time passes after the surgery.

Another subforum is "our experiences". This forum includes 64 sub-subjects, the most read and responded topic is "Is There Anyone Using Needle For Tendon Development?", having many questions about spinal cord injuries. This topic receives high attention from the members with a broad range of diseases. Thus, many members shared their experiences in this topic. One of the members stated as below:

"Dear friends, I am sharing my experiences after some time. Cortexin Treatment is still on. Now I get treatment for 10 days, and have a break for 20 days. After I receive the treatment four more times, in total it will be 90. My six years old son has incredible progress in movement, perception and expression and progress is getting better. I was never hopless when I started this needle, I never took negative people and their words into consideration, I determined my way positively and going that way. My most important advice will be to decide after talking to your doctor, and don't consider any negative or positive information getting from unreliable people. Talk to you later."

\section{News and sports}

There are four sub-forums in this section. 1834 sub-subject and 2756 responses exist in the topic titled "News and Advancements about Disabled People" As in the other forums, the most remarkable issue is the importance given to the news related to diseases and treatments. The most attractive sub-forum under "News and Advancements about Disabled People" is "News about Disabled People in Turkey", having 1634 sub-topics and 2318 responses. Most attractive sub-topic is "Walking Hope for Paralyzed People". The statement below was shared by a member and read by a lot of members.

"A doctor in a private hospital stated in a press conference that lokomat machine, that there are only five of them in Turkey and two of the machines are in the center where this doctor works, has a positive effect on the treatment in early period of cerebral palsy, spinal cord injuries, brain injuries, spinal cord tumors, spastic children and 
multiple skleroz (MS). The doctor says that this machine is not only to make the patients walk, also help people who have sitting problem about their balances, and ease the spasm problems of the patients. The doctor says that the number of the sessions will differ according to the patient, and he also says that they can understand in ten sessions whether the patients can walk again. According to the doctor, they use this machine for one month and 13 of the 15 paralyzed patients started walking again, and treatment for the other two patients continue. One patient said that he had brain hemorrhage (bleeding) one year ago, was discharged from the hospital 10 months ago and after the treatment he had in the last month, he started walking again.

\section{Disabled People General Section}

In this section, the sub-forum titled "Critical Sections" is most read and has the highest number of sub-subject. This forum includes many topics related to disability and human rights. The most attractive sub-forum here is "Fighting Discrimination, Human, Society, Today-Tomorrow", having "What are the Most Disturbing Behaviors When You are in a Society" as a sub-subject with highest attention and actively consideration. Many people shared similar experiences in this subject. One of the members shared the statement below:

"In some places, people treat me like a potential beggar. In some places, they act like I am happy with my situation, or they make me feel me like that. In the first years, they were talking from my behind, saying how young I was. Once or twice, they thought the hospital owned my wheelchair and they asked it from me. Once, an old lady asked me to sit on the floor so her husband could use the wheelchair also. I responded as if I can manage to get up and sit on the floor, I would give my wheelchair to him as a gift."

One of the member expressed his feelings with a poem in the forum:

"In a desert where there is no equality,

My words are useless,

That's the reason for my silence,

Nobody will hear if I talk,

And all my cells will be in riot, if I get silent".

\section{Life in General Topics}

Under this forum, members share their thoughts in nine different sub-forums related to specific topics like culture, Islam and people, and media. Health issues have the highest attention even though the forum is related to real life issues. The forum "Current Health News" has 1224 subjects, and "Pain and Numbness on Neck, Head, Back, Arms May be the News for Neck Hernia" is the most read sub-forum. Islamic Video and Trailers" has the second highest subjects number with "Letter from the Grave" as the most read subject. Similarly, "Religious Stories" includes many subjects and most read topic is "Nice Stories Between Polat and Father Omer". One of the members shared as story as shown below:

"Once upon a time the Prophet Suleyman gets on his flying carpet and started looking around his country. He was charmed with the beauty saying I own very beautiful places and things. Then the carpet started bowing. After Suleyman realized that the carpet is bowing, he said straighten up to the carpet. Carpet kept bowing and 
receives another warning from the Prophet saying "I am the sultan Suleyman". The carpet kept bowing. Then Suleyman said I am the Prophet Suleyman, straighten up. When Prophet Suleyman is close to fall, he said to the carpet I said straighten up. Then the carpet replied: you should straighten up Suleyman, all of these belong to the God, don't think you are the reason of everything. As long as you don't see yourself as the reason, nothing can charm you. If it charms you, straighten yourself up, not the carpet."

\section{Entertainment-Conversation}

The forum titled "Fun and Conversation" includes sub-forums. Fun has the highest attention under the sub-forums. "Love" section of this forum has the highest amount subject. The sub-forums titled "Love Poems", "Poems with Pictures" have the highest number of topics. Members read "Poems with Pictures" 4308 times. The member shared a poem which was read most:

"My intention was to smile and to make someone smile,

You took the light behind my eyes,

I see no smile

What did I do to you?

You owe me a life

Explain that."

\section{CONCLUSIONS}

In this paper the researchers explored why patients with chronic diseases want to share their experiences in the virtual community. More precisely, this netnographic study was aimed to reveal the experiences of a virtual community comprised patients with spinal cord paralysis. The results of this study indicated that six main forums emerged including 'current issues', 'spinal cord injury general', 'news and sports', 'disabled people general section', 'life in general topics', and 'entertainment-conversation'. The most important finding in this study was that virtual community concerning with spinal cord paralysis is used as means to obtain information related to the chronic disease. This finding is in line with the suggestion that virtual communities are common knowledge-sharing tools (Chen, Chang \& Liu, 2012). As indicated by Loane \& D'Alessandro (2013), dynamic interchangeable health information and socio-psychological support are main determinants of virtual community for patients with SCI. The information can also often related to sustaining care and a better quality of life of the disease. Thus, Gehart (1997) argued that need accurate information for people with SCI is essential in terms of possibility for quality living following injury. Additionally, it should be noted that willingness to provide spiritual strength is one of the most important benefits of this kind of virtual communities.

Chronic diseases creating difficulty in moving is also difficult to establish interaction based on physical contact. For this reason, virtual communities and social media can be characterized as a socializing tool. These findings are in line with experiences of many chronic disease. Consistent with our study's findings, previous research indicates that online group applications have the potential to support the ongoing care needs of patients with chronic disease (Goldberg et al., 2003). However, few studies have examined the role of 
virtual communities on chronic disease from the perspectives of patients with SCI. A better understanding of the role of social media and virtual groups on patients is important for reasons of health improving, socialization, psychological wellbeing and so on. As indicated by Camerini, Diviani and Tardini (2010) virtual health communities play an important role in both establish social relationships and develop these relationships, and to obtain and share information. A better understanding of domains in chronic patients' experiences that are very important to patients with SCI will help the people to better understand and interpret the chronic patients in same situation. Social and psychological aspects concerning patients with chronic disease did not explain much of the living experiences in their routine life. In contrast, shares-related virtual community is the most important indicator in spinal cord injuring. Thus, these patients with chronic disease is to interact with people who will understand them best. Therefore, in a country of little importance attributed disabled, interaction or shares in a virtual environment was the most important contributor channel for Turkish patients with spinal cord injured.

The results of this qualitative netnography study may provide significant implications to society in their effort to integrate these patients, in various dimensions including motivation, psychological and social support, landscaping disabled citizens, and therapeutic recreation possibilities. The findings of the study suggest the need for changes of virtual community perception and group interaction experiences. As might be expected, it is found that interest in the medical news relating to the hope of recovery was the most important factor. Furthermore, religious and other experiences of living were found to be key findings. Therefore, the support of the other patients with the same disease and the environment are required in order to raise life expectancy. Additionally, engaging and giving new experiences to patient with SCI can be improve commitment and life willingness to overcome the trauma disorders and marginalized community. In conclusion, the results of this study highlight that some of potential approaches that can make life livable for patients with SCI and also their relatives, as concluded by Loane and D' Alessandro (2013).

The satisfaction with information and experience sharing was associates with effectiveness of virtual health community. The possible explanations for effectiveness are that the number of members in the patient-centered virtual community, the ratio of share, the level of interest in reading, and the attractiveness. Interestingly, sharing ratio, reading level and answering the level in virtual community for SCI were related to patient or member satisfaction with the importance of the information, value of shares, and updating.

The results also suggest new approach to chronic disease and netnographic research methods for people with serious health problems. The use of qualitative netnographic study enabled the potential researchers to explore the data rapidly and in great depth. For this reason, netnographic studies in health also have a potential use in the therapy of many chronic diseases.

\section{LIMITATIONS AND FURTHER RESEARCH}

This netnographic study has several limitations. As with all qualitative research, interpretation the results is limited by only one specific virtual community. The researchers evaluated patients' experiences on a special virtual group. Looking at only one virtual community dedicated to a specific population limited the range of data. More precisely, 
patients with spinal cord injured may not representative groups of other same groups and other chronic diseases. The data were collected over a limited time period. Furthermore, this netnography data was descriptive and exploratory, and not designed for quantitative hypothesis testing. Future studies may look at the different specific disease groups. Additionally, future studies should expand the population both number and geographically.

\section{REFERENCES}

Annett-Hitchcock, K. \& Xu, Y. (2015). Shopping and Virtual Communities for Consumers with Physical Disabilities. International Journal of Consumer Studies, 39, 136-144.

Bratucu, R., Gheorghe, I. R., Radu, A. \& Purcarea, V. L. (2014). The Relevance of Netnography to The Harness of Romanian Health Care Electronic Word-Of-Mouth. Journal of Medicine and Life, 17(3), 363-367.

Camerini, C., Diviani, N. \& Tardini, S. (2010). Health Virtual Communities: Is The Self Lost in The Net? Social Semiotics, 20(1), 87-102.

Chen, C. S., Chang, S. F. \& Liu, C. H. (2012). Understanding Knowledge-Sharing Motivation, Incentive Mechanism, and Satisfaction in Virtual Communities. Social Behavior and Personality, 40(4), 639-648.

Davis, D. Z. \& Calitz, W. (2014). Finding Healthcare Support in Online Communities: An Exploration of The Evaluation and Efficacy of Virtual Support Groups. Journal of Virtual Worlds Research, 7(3), 1-16.

Demiris, G. (2006). The Diffusion of Virtual Communities in Health Care: Concepts and Challenges. Patient Education and Counselling, 62, 178-188.

Eysenbach, G., Powell, J., Englesakis, M., Rizo, C. \& Stern, A. (2004). Health Related Virtual Communities and Electronic Support Groups: Sytematic Review of The Effects of Online Peer to Peer Interaction. BMJ, 328, 1-6.

Gehart, K. A. (1997). Quality of Life: The Danger of Differing Perceptions. Topics Spinal Cord Injury Rehabilitation, 2, 78-84.

Goldberg, H. I., Ralston, J. D. Hirsch, I. B.; Hoath, J. I. \& Ahmed, K. I. (2003). Using an Internet Comanagement Module to Improve The Quality of Chronic Disease Care. The Joint Commission Journal on Quality and Patient Safety, 29(9), 443-451.

Greene, J. A., Choudhry, N, K., Kilabuk, E. \& Shrank, W. H. (2011). Online Social Networking by Patients with Diabetes: A Qualitative Evaluation of Communication with Facebook. Journal of General Internal Medicine, 26(3), 287-292.

Hartley, J. (2004). Case study research in Cassell, C. \& Symon, G. (Eds), Essential Guide to Qualitative Methods in Organizational Research, Sage, London, pp.323-333.

Hoybye, M. T. Johansen, C. \& Tjornhoj-Thomse, T. (2005). Online Interaction. Effects of Storytelling in an Internet Breast Cancer Support Group. Psychooncology, 14, 211-220. 
Huang, K-Y., Chengalur-Smith, I.S. \& Ran, W. (2014). Not Just for Support: Companionship Activities in Health Care Virtual Support Communities. Communications of the Association for Information Systems, 34(29), 561-594.

Keeling, D., Khan, A. \& Newholm, T. (2013). Internet Forums and Negotiation of Healthcare Knowledge Cultures. Journal of Service Marketing, 27(1), 59-75.

Klemm, P., Hurst, M., Dearhold, S. L. \& Trone, S.R. (1999). Gender Differences on Internet Cancer Support Groups. Computers in Nursing, 17, 65-72.

Kozinets, R. V. (1997). "I Want to Believe:" A Netnography of The X-Philes' Subculture of Consumption. Advances in Consumer Research, 24, 470-475.

Kozinets, R. V. (1998). On Netnography: Initial Reflections on Consumer Research Investigations of Cyberculture. Advances in Consumer Research, 25, 366-371.

Kozinets, R. V. (1999). E-Tribalized Marketing? The Strategic Investigations of Virtual Communities of Consumption. European Management Journal, 17, 252-264.

Kozinets, R. V. (2002). The Field Behind The Screen: Using Netnography for Marketing Research in Online Communities. Journal of Marketing Research, 39, 61-72.

Kozinets, R. V. (2006). Click to Connect: Netnography and Trivial Advertising. Journal of Advertising Research, 46(3), 279-288.

Kurtaran, A., Akbal, A., Ersöz, M., Selçuk, B., Yalçın, E. \& Akyüz, M. (2009). Occupation in Spinal Cord Injury Patients in Turkey. Spinal Cord, 47, 709-712.

Lee, F. S. L., Vogel, D. \& Limayem, M. (2003). Virtual Community Informatics: A Review and Research Agenda. JITTA: Journal of Infarmation Technology Theory and Application, 5 (1), 47-61.

La Rocca, A., Mandelli, A. \& Snehota, I. (2014). Netnography Approach as a Tool For Marketing Research: The Case of Dash-P \& G/TTV. Management Decision, 52 (4), 689704.

Loane, S. S. \& D'Alessandro, S. (2013). Communication that Changes Lives: Social Support within an Online Health Community For ALS. Communication Quarterly, 61(2), 236251.

O'Reilly, N., Berger, I. E., Hernandez, T., Parent, M. M. \& Seguin, B. (2012). Understanding Adolescent Sport Participation through Online Social Media. Sport, Business and Management: An International Journal, 2(1), 69-81.

O'Reilly, N. J., Rahinel, R., Foster, M. K. \& Patterson, M. (2007). Connecting in Megaclasses: The Netnographic Advantage. Journal of Marketing Education, 29(1), 69-84.

Pettigrew, S., Pescud, M., Jarvis, W. \& Webb, D. (2013). Teens' Blog Accounts of The Role of Adults in Youth Alcohol Consumption. Journal of Social Marketing, 3(1), 28-40.

Rageh, A., Melewar, T. C. \& Woodside, A. (2013). Using Netnography Research Method to Reveal The Underlying Dimensions of The Customer/Tourist Experience. Qualitative Market Research, 16 (2), 126-149. 
Sayılır, S., Ersöz, M. \& Yalçın, S. (2013). Comparison of Urodynamic Findings in Patients with Up and Lower Cervical Spinal Cord Injury. Spinal Cord, 51, 780-783.

Sigala, M. (2012). Social Networks and Customer Involvement in New Service Development (NSD). International Journal of Contemporary Hospitality Management, 24 (7), 966-990.

Symister, P. \& Friend, R. (2003). The Influence of Social Support and Problematic Support on Optimism and Depression in Chronic Illness. A Prospective Study Evaluating SelfEsteem as Mediator. Health Psychology, 22 (2), 123-129.

Welbourne, J. L., Blanchard, A. \& Wadsworth, M. B. (2013). Motivations in Virtual Health Communities and Their Relationship to Community, Connectedness and Stress. Computers in Human Behaviors, 29, 129-139.

Winkelman, W. J. \& Choo, C. W. (2012). Provider-Sponsored Virtual Communities for Chronic Patients: Improving Health Outcomes Through Organizational PatientCentered Knowledge Management. Health Expectations, 6, 352-358.

Yılmaz, T., Turan, Y. \& Keleş, A. (2014). Pathophysiology of The Spinal Cord Injury. Journal of Clinical and Experimental Investigations-JCEI, 5(1), 131-136. 